\title{
Complexity of culture and entrepreneurial practice
}

\author{
Kerstin Bätz, Patrick Siegfried
}

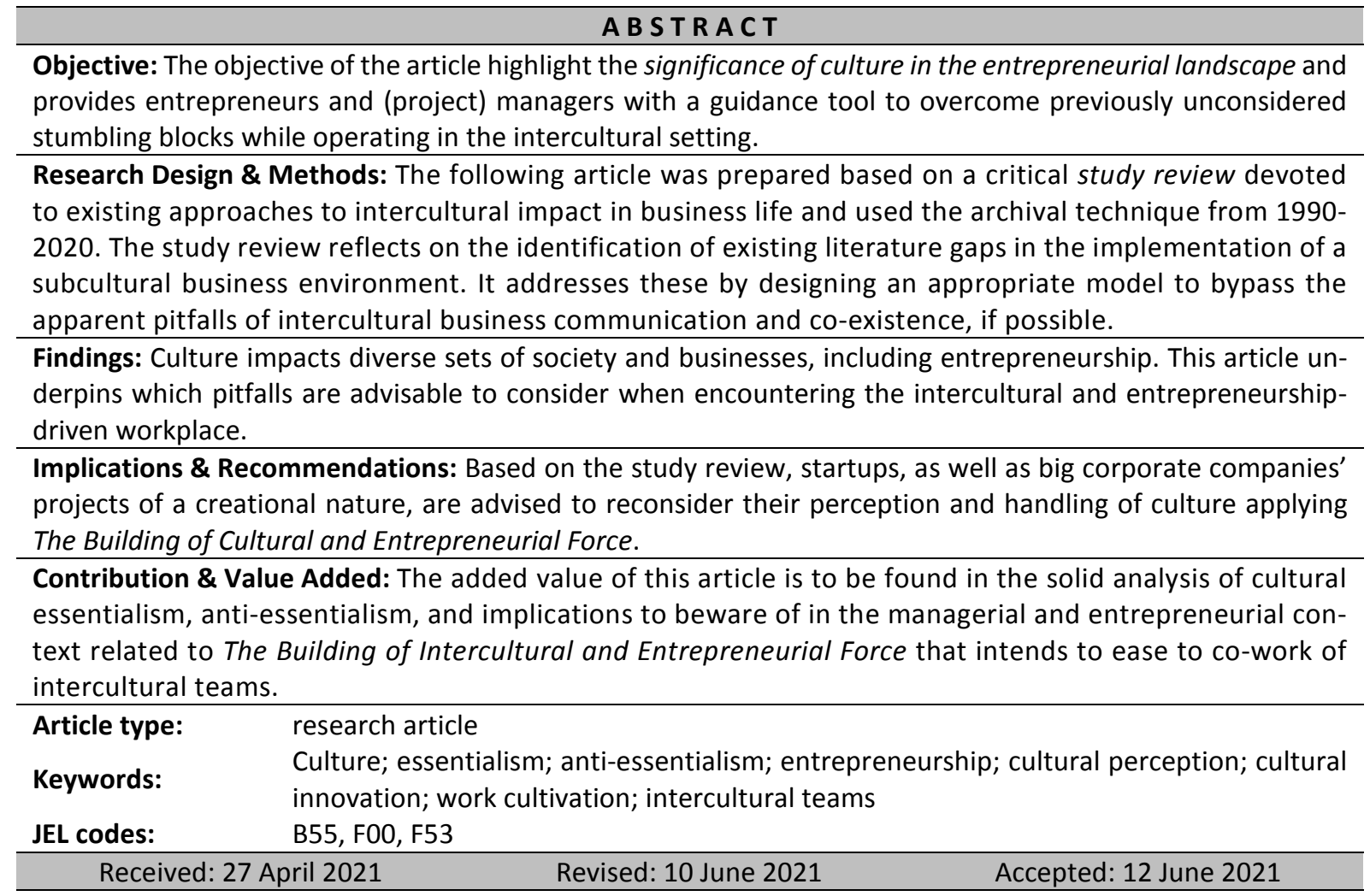

\section{Suggested citation:}

Bätz, K. \& Siegfried, P. (2021).Complexity of culture and entrepreneurial practice. International Entrepreneurship Review, 7(3), 61-70. https://doi.org/10.15678/IER.2021.0703.05

\section{INTRODUCTION}

This paper attempts to explore the interaction between culture and entrepreneurship. Entrepreneurship is increasingly being recognized as an important factor for economic growth. Some cultures are more conducive for entrepreneurship than others, considering the different cultural heritages and dimensions. The significance of different cultural aspects and their effect on entrepreneurship has been noted in a number of studies (cf. Wach, 2015). Therefore, as culture is a relatively unconscious framework based on a shared understanding that can vary, the objective of the article is to highlight the significance of culture in the entrepreneurial landscape to provides entrepreneurs and (project) managers with a guidance tool to overcome previously unconsidered stumbling blocks while operating in the intercultural setting (cf. Bartha et al., 2018; Kaasa et al., 2013), providing this article with sufficient novelty. Thus, the assumptions on which this article is based on are as follows: 
A1: The anti-essentialist approach disregards entrepreneurship.

A2: Existing cultural approaches do not yet provide entrepreneurship with a framework to leverage its intercultural setting.

Culture can provide a system of commonly shared meaning, interpretation, and values (Primecz et al., 2009; cf. Hall, 1959, 1976; Holliday, 2011; Søderberg \& Holden, 2002; Trompenaars \& HampdenTurner, 1997). According to Søderberg and Holden (2002), culture is related to the notion of social constructivism. In that case, it is a collective and relational construct that can be defined and redefined by those participating. Thus culture is based on a mutable construction. "Culture used to be a way to describe, generalize and explain what a person was doing. Itis not so easy - maybe even impossible to do that anymore" (Agar, 2002, p. 15).

The complex and dynamic construct of a culture built upon interpersonal communication processes, co-existence, and behavior does not remain consistent in its values and practices since it is a negotiable social process of change (cf. Bartha et al., 2018; Kaasa et al., 2013). That proceeding tends to happen on a presumably unconscious level. The relational construct refers to the interaction of people who belong to the same particular culture. Simultaneously these people are catalysts for a new emergent contextual setting of visions, aspirations, and change (cf. Olwig, 1997; contra. Hall, 1959, 1976; Hofstede, 1980; Søderberg \& Holden, 2002; Trompenaars \& Hampden-Turner, 1997). Consequently, culture can adapt and integrate novelty, unifying the old and new practices (cf. Clausen, 2010; Fischer et al., 2014; Flitzsimmons, 2013; Hannerz, 1996; Joy \& Poonamallee, 2013; Primecz et al., 2009; Søderberg \& Holden, 2002; contra. Hall, 1959, 1976).

Similar to culture, business, especially entrepreneurship, is a never stagnant process - culture is in continuous progress, a related structure can be found in entrepreneurship. However, this circumstance in the entrepreneurial context is not only driven by desirable states of cultural diversity but also much more by the competitive nature and accompanying innovation in a business world that is increasingly VUCA: volatile, uncertain, complex, ambiguous (Bennett \& Lemoine, 2014; cf. Kim \& Mauborgne, 2015). "Entrepreneurship necessarily takes place within culture, it is utterly shaped b culture, and it fundamentally consists in interpreting and influencing culture. Consequently, the [entrepreneur] can understand it only if he is willing to immerse himself in the cultural context in which the entrepreneurial process occurs"(Lavoie 1991, p. 36).

In particular, entrepreneurs with the will to make progress accessible to entire economies use creative diversity, skill sets, and in the same process, acquire an awareness of the significance of cultural diversity. Thus, multidisciplinary teams are increasing in frequency, as they are said to meet not in their weaknesses but complementarily in their strengths (Bartha et al., 2018; Weinberg, 2019). Multidisciplinary teams promote the learning of cooperativeness and solution-oriented action and openness and exposure to new ideas (Weinberg, 2019; cf. Di Cristini et al., 2003; Lewrick et al., 2018; Pearce, 2003). Multidisciplinarity, however, expands to the analysis of hard and soft skills, but cultural diversity simultaneously. A variance of this kind may not only result in a holistic go-to-market strategy of an emerging startup but also indicate unavoidable knowledge about global markets and their particular characteristics (cf. Nathan, 2014). Ignoring these characteristics could negatively impact a born global in the market entry phase and its market power (contra. Habermann, 2008; Kaplan, 1966; Rumelt, 2011; Voloshinov et al., 1973).

Therefore, shared leadership (Di Cristini et al., 2003; Pearce, 2003; cf. Myers, 1962) and flat or no hierarchies are beneficial in startups with the desire to be competitive (cf. Weinberg, 2019), as collaborative team working for and with the same vision (Sinek, 2009) is critical to the breakthrough entrepreneurial success of a founding team.

\section{LITERATURE REVIEW AND THEORY DEVELOMENT}

\section{Reviewing Culture's Complexity}

Even though practiced with superb intentions, approaching cultural otherness in the entrepreneurial context of a multidisciplinary, intercultural team (cf.; Kaasa et al., 2013; Weinberg, 2019) can cause 
frictions unconsciously. The rather one-dimensional approach to categorizing the complex dynamic and mutable construct of culture implies the potential of becoming increasingly tricky in its utilization (Primecz et al., 2009; cf. Clausen, 2010; Hannerz, 1996; Søderberg \& Holden, 2002; contra. Hall, 1976) since culture is inappropriate to perceive as nation-based (contra. Hofstede, 1980). Cultural diversification is inextricably related to the notion of vastly growing globalization (Cheung \& Chan, 2009; cf. Szromnik, 2020) and its diverse microcultures' facets. "The world is full of confrontations between people, groups, and nations who think, feel, and act differently. At the same time these people, groups, and nations, [...] are exposed to common problems that demand cooperation for their solution" (Hofstede \&Minkov, 2010, p. 10).Consequently, national cultures appear to emancipate themselves automatically from standardized norms - against essentialists' assumptions (contra. Hofstede, 1980) - and similar to innovation-driven startups. Respectively, the anti-essentialism paradigm underpins that culture extends beyond the standstill. The opposite would imply that neither further development nor learning in a mental framework would occur, which can be seen from an anthropologist's and behaviorist's perspective on culture, as invalid as well (cf. Kahn, 2001; contra. Hofstede, 1980; Hall, 1959).

Generalizing individuals from a presumably shared cultural background as practiced by cultural essentialists can imply the apparent risk of educational convenience. The result of mental impartiality may lead to the prevention of intercultural progress and efforts (cf. Bartha et al., 2018; Kaasa et al., 2013). That can harm a respectful - even face-maintaining - co-existence in an emergent company that is reliant on its internal functionality (Bond, 1991; Hu, 1944; Mao, 1994; Pan, 2000, Spencer-Oatey, 2002; cf. Gorski, 2013; contra. Wendt \& Gone, 2011). Resultantly, disrespectful social interactions (contra. Bartha, Gubik \& Bereczk, 2018) in the entrepreneurial setting are accompanied by the jeopardy of preventing the progress of cultural sensitivity (cf. Bennett, 2017; contra. Earley \& Mosakowski, 2004). As startups often lack this internal stability based on cultural mindfulness due to the novel and never experienced an overall situation, team-internal problems reported causing $23 \%$ of startups' failure (cf. StartUpWissen, 2020; t3n, 2016).

Contrastingly, cultural sensemaking and the desire to gain a richer understanding of cultures distinct from the familiar can make a valuable contribution to economic progress (Bennett, 2017; cf. Weinberg, 2019). Therefore, cultural sensemaking can be appreciated as it may result in the ability to acquire causality and a broader understanding of the counterpart's behavioral practice. That includes the change of cultural perspective (Bhatti et al., 2020; Hassan et al., 2021) and ethnorelativism: the existence of numerous viable possibilities for perceiving culture's reality (Bennett, 2017; cf. Hannerz, 1996).

Additionally, by categorizing and generalizing culture and individuals, principles of cultural ontology are likely to be violated as the essentialist paradigm links identity to the broader concept of national origin and measures national-geographical criteria (Sayer, 1997; contra. Hofstede, 2002) predominantly. That essentialist's approach practice could work counterproductively on the self-fulfillment needs and the cultural self-awareness beliefs of those the generalizing conversation's part encounters (Deardorff et al., 2012; cf. Maslow, 1943; contra. Sayer, 1997).

Gorski (2013) claims that the anti-essentialism approach regards political, interpersonal, and ethnographical mindfulness. The usage of stereotypes is said to disregard gender and the ethnicity of individuals that might refer to a hybrid ethnical background (cf. Friedman, 1994; Scollon \& Scollon 2001; contra. Hall, 1976). "The need to make sustained and serious progress toward ethnic and racial justice is clear" (McKinsey \& Company, 2020, p. 2). This statement is increasingly important considering the currently ongoing Black Lives Matter movement that fights for societal equality for all ethnic groups, aiming to combat ethnic-based injustice (cf. De Genova, 2016; Swart \& Maralack, 2020; Taylor, 2016).

By focusing on cultural complexity, the anti-essentialist statements above emphasize the relevance of ethnic variety in entrepreneurship (Hassan et al., 2021; Lauring et al., 2018; cf. Clausen, 2010; contra. Hofstede, 1980). Hence, it is advisable to perceive culture as a continuously and socially constructed process (Søderberg \& Holden, 2002; cf. Bartha et al., 2018; Sayer, 1997; contra. Hofstede, 2002). Also, emergent companies should recall the consciousness that culture can be a reassessed and redesigned, reinforcing the emergence of a negotiated culture, even in an economic 
setting (Clausen, 2010; Søderberg \& Holden, 2002; Sayer, 1997; contra. Hall, 1959). That knowledge of cultural otherness can encourage intercultural encounters to create a shared cultural complexity similar to shared leadership where every participant is accountable for the outcome. More clearly: shared leadership and cultural complexity have in common that culture is a mutually accountable process (cf. Pearce, 2003).

Thus, not only culture, but global entrepreneurship too (cf. Hassan et al., 2021), move towards a global melting pot of shared ideas (McKinsey \& Company, 1993; Søderberg \& Holden, 2002; cf. Gorski, 2013; contra. Hofstede, 2002). Ostensibly, the likelihood of unintendedly disrespecting the set of norms and values individuals refer to increases. It must be underpinned that global togetherness is not equal to emancipating the self from the individual set of societal expectations of politeness, education, or language taught. As a result, the promising melting of cultures implies potential pitfalls, reinforcing the urgency to examine blind spots evident in the entrepreneurial intercultural setting (cf. Hassan et al., 2021).

\section{Building Intercultural and Entrepreneurial Force}

It is known that entrepreneurship is increasing in its popularity. "The decision to start a venture has both cultural and economic [reasons]" (Radziszewska, 2014).Visionaries, game-changers, and challengers demand and foster the change of entire industries (cf. Christensen, 2016). However, interculturality is a topic relevant to an entrepreneur's success and harmonious business excellence either as elaborated above. International business partners can access globalized networks - obviating a born global's economic jeopardy of running the liability of outsidership (cf. Cheung \& Chan, 2009; Johanson \& Vahlne, 2009; Singh et al., 1986; Wach, 2016). Operating interculturally is respectively an essential element for born global startups (McKinsey \& Company, 1993). Additionally, referring to the current political movement Black Lives Matter, mutual understanding and efforts towards cultural alterations demand severe overdue changes (cf. Bennett, 2017; De Genova, 2016; Taylor, 2016; contra. Hofstede, 1980).

Nevertheless, strategic but interpersonal and intercultural skills should increase to maximize international entrepreneurial prosperity (Bennett, 2017; Radziszewska, 2014; cf. Earley \& Mosakowski, 2004; Hassan et al., 2021). However, as merely addressing the significance of practicing cultural inclusion in the media instead of providing the economy guidance on how to shed light on the examination of cultural otherness to be leveraged, perform an entrepreneur's managerial duty (Drucker, 2006) fashionably. The following model on The Building of Intercultural and Entrepreneurial Force serves as a tool for economic, cultural game-changers to help realize their anticipated success.

The fundament builds upon the vision. It is built through a diverse team that engages in creating a socially constructed genre (cf. Bartha et al., 2018). For this, the project's participants should employ cultural intelligence to enable the emergence of common ground: the first attempt of a negotiated multi-culture. Further, communicating and agreeing on shared values enhance the likelihood of a sociologically empathetic mindful working environment, fostering commercial and entrepreneurial success (Earley \& Mosakowski, 2004; Pearce \& Conger, 2002; cf. Hassan et al.,2021; Sinek, 2011; contra. Hall, 1959). However, for the vision's unambiguous interpretation, it should be considered that interpretations may differ due to the culture's complexity and variety. Evading misinterpretations should be reinforced by clear communication to achieve the common economic goal with the shared vision (cf. Bargiela-Chiappini \& Nickerson, 1999; Clausen, 2010; Lauring et al., 2018; Usunier, 2011). Additionally, an in-depth examination of the vision's and communication's meaning is advisable as proximity breeds mindfulness whereas distance breeds failure (cf. StartUpWissen, 2020; t3n, 2016; contra. Earley \& Mosakowski, 2004; Habermann, 2008; Kaplan, 1966; Pearce \& Conger, 2002; Voloshinov et al., 1973). 


\section{The Building of Intercultural and Entrepreneurial Excellence}

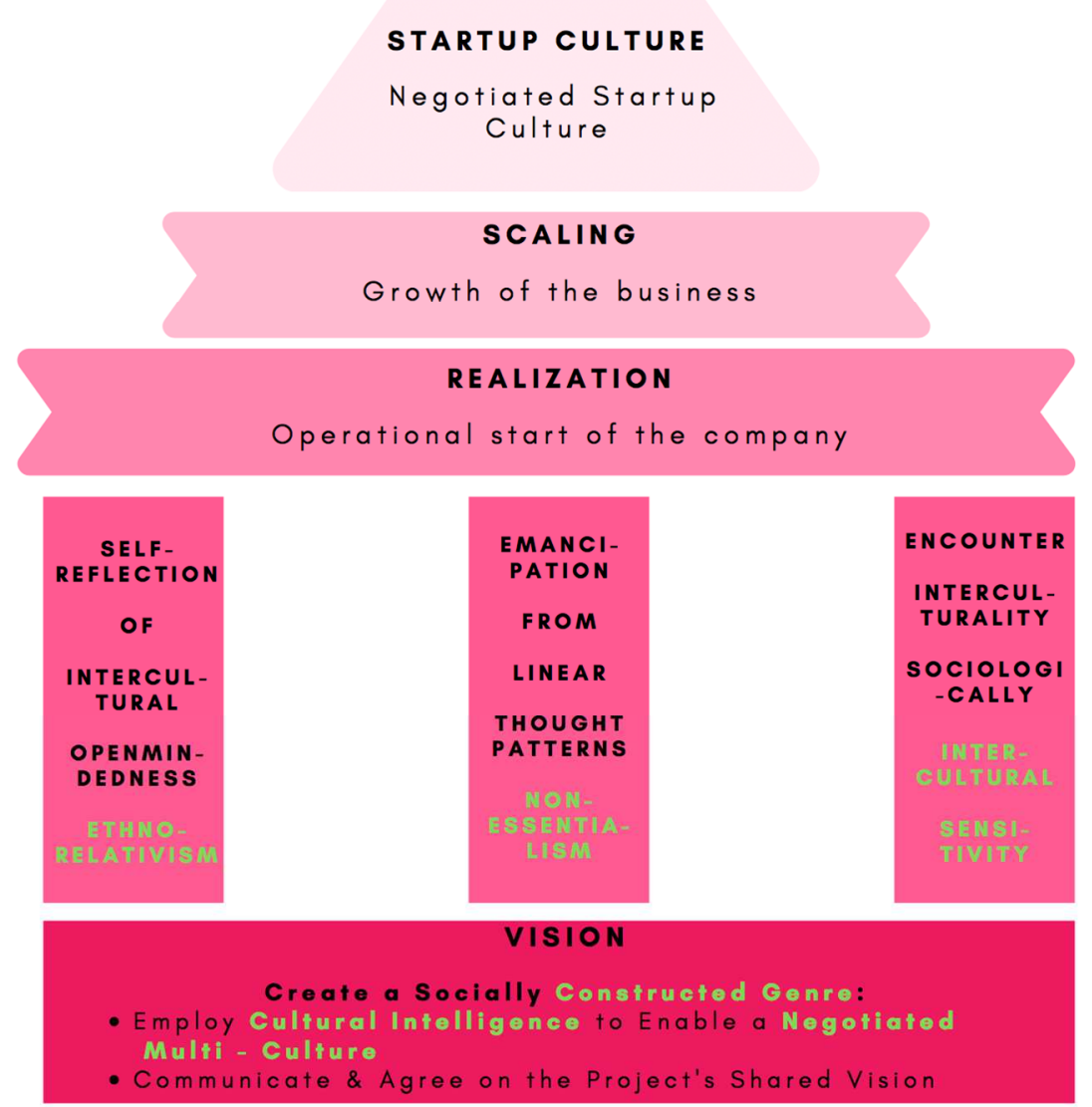

Figure 1. The Building of Intercultural and Entrepreneurial Force Source: own elaboration.

The three pillars encourage interculturality in an entrepreneurial scope, catalyzing mutual intercultural understanding efforts. The pillars provide information on how to grow together to become a successful intercultural team:

- Self-Reflection of Intercultural Sensitivity (Ethnorelativism): Reassess ethnorelativism. One should remember to remain open-minded towards cultural otherness for the shared success.

- Emancipation From Linear Thought Patterns (Non-Essentialism): Approaching the intercultural encounter as diversity is an enrichment in its excellence. There are numerous viable realities of intercultural entrepreneurship.

- Encountering Interculturality Sociologically (Intercultural Sensitivity): Showing cultural absorptive capacity through mirroring gestures and customs distinct is beneficial. Nonetheless, one should not forget about their cultural background. Showing sociological empathy is advisable.

Notwithstanding, the emergence of one key issue should be addressed: generalizing not only one's national culture but work practices (contra. Hall, 1959, 1976; Hofstede, 1980; Trompenaars \& Hampden-Turner, 1997). Here, the judgmental thinking in a working environment (contra. Gorski, 2013) that is as dynamic and vulnerable due to its novelty can decrease performance. Thus, an unbiased and explorative mindset cannot only increase the harmonious working atmosphere but creativity, too (cf. Earley \& Mosakowski, 2004; Festinger, 1957; Primecz et al.,2009; contra. Hofstede, 1980).

After the three pillars, reaching the operational realization stage of the startup is economically promising and fruitful as it enables the scaling stage to begin shortly after. Resultantly, throughout the entire process that is presumably never-ending, a new negotiated startup culture with the project's 
unique genre that all participants constructed emerge (Clausen, 2010; Søderberg \& Holden, 2002; contra. Hall, 1959). It might find its reliable structures with first economic success as real-life circumstances are experienced for the first time.

Those reliable structures can create a feeling of togetherness and increase the inevitable working efficiency (cf. Ries, 2014). In contrast, it should be taken into account that individuals might differ in their understanding of togetherness in the new contextual setting (cf. Olwig, 1997). Hence, they might still perceive the new emergent culture as part of the occupation only, reflecting the failure on the vision's relevance (contra. Sinek, 2011).

\section{CONCLUSIONS}

\section{Summary of results}

In summary, it was identified that the Essentialist approach to culture is not contemporary with the ever-changing context of economic growth, which is mainly driven by the upward trend of entrepreneurship. The stylistic approach of arranging individuals of a geographically arranged culture does not consider the nuances and hybrid histories of individuals but tends to generalize people, contrary to the nature of being.

Although the anti-essentialist approach on culture criticizes and tries to overcome these very stumbling blocks of the essentialist approach by emphasizing the individual, this approach, although an advance of the initial approach, is not yet sufficient in the entrepreneurial context, since here not only the subjective culture but also the subjective perception of culture and work meet. In order to create a symbiosis of both, The Building of Intercultural and Entrepreneurial Force is intended to serve entrepreneurs and (project) managers, but generally, all those who want to participate in the growth of the cognitive maturation process in a business landscape, as a thinking aid for self-reflection towards progress.

\section{Managerial implications}

As practical and managerial implications of this study review, it can be deduced that (project) managers - especially entrepreneurs - who are constantly facing new challenges have to deal with their composition and dynamics of the team. Thus, this process starts with the team's most senior member by acquiring the awareness and the need for understanding cultural otherness. That cognitive process should be complemented by an open feedback culture but must be separated from reproachful jargon.

In addition, the process of critical self-reflection should go beyond the self and address the perceptions of the wider participating team members. The transformation to culturally aware work can only happen through shared cognition and sensitivity. At the same time, open, respectful communication and the ability of self-reflection are sharpened. However, it must be remembered that patience and tolerance for error are as ready for this process as acknowledging and understanding cultural otherness itself. Emphasizing error feeds further errors. Fixing errors through patience and mutual understanding paves the way for sustained, effective co-work. The Building of Intercultural and Entrepreneurial Force serves as a guideline for visionaries, enabling them to engage in societal and economic change, contributing in a promising way as not only startups but those demanding cultural thought pattern change can leverage their inherent power towards closing the gap of ethical and economic injustice.

\section{Research Limitations}

This article reaches its limits of expressiveness as existing literature regarding approaches to cultural other concepts were reflected. No confirmed case study was conducted to prove or disprove the findings of this article.

Furthermore, The Building of Intercultural Force is arguably not a linear tool that provides predictive insight into behaviors (cf. Olwig, 1997; contra. Hofstede, 1980) and business success-due to the complex and dynamic nature of culture rooted in the interactive communication of processes of individuals, and the increasingly VUCA (volatile; uncertain, complex, ambiguous) (Bennett \& Lemoine, 
2014). A business landscape with its drive for radical innovation does not stand still but strives for the unpredictable richness of continuous change. Neither a framework, nor a model, nor an analytical tool introduced to the robust entrepreneurial mindset guarantees a higher, validated degree of certainty, as the prosperity state of success is subject to practitioner application.

\section{Suggestions for further research}

Further research should be directed towards underpinning the present article with sufficient real life cases that either prove or refute The Building of Intercultural Force's academic expressiveness. Additionally, future research should consider the team's internal interculturality, and the country-specific distribution should ideally take place across all continents on a random basis so that representative results can support the study review. Only in this way can it be determined whether the identified gaps in the existing literature have been served.

\section{REFERENCES}

Agar, N. (2002). Agar's Review of Katz. Biology \& Philosophy, 17 (1), 123-139.

Bargiela-Chiappini, F.,\& Nickerson, C. R. (1999). Writing business: Genres, media, and discourses. Longman.

Bartha, Z. S., Gubik, A., \& Bereczk, A. (2018). The Social Dimension of the Entrepreneurial Motivation in the Central and Eastern European Countries. Entrepreneurial Business and Economics Review, 7(1), 9-27. https://doi.org/10.15678/EBER.2019.070101

Bennett, J. M. (2017). Developmental Model of Intercultural Sensitivity. John Wiley \& Sons.

Bennett, N., \& Lemoine, J. (2014). What VUCA really means for you. Harvard Business Review, 92 (1), 27-28.

Bhatti, A., Rehman, S. U., \& Rumman, J. (2020). Organizational capabilities mediates between organizational culture, entrepreneurial orientation, and organizational performance of SMEs in Pakistan. Entrepreneurial Business and Economics Review, 8(4), 85-103. https://doi.org/10.15678/EBER.2020.080405

Bond, M. H. (1991) Beyond the Chinese Face, insights from psychology. Oxford University Press.

Cheung, M. W.-L.,\& Chan, W. (2009). A Two-Stage Approach to Synthesizing Covariance Matrices in Meta-AnaIytic Structural Equation Modeling. Structural Equation Modeling A Multidisciplinary Journal,16 (1), 28-53. https://doi,org/10.1080/10705510802561295

Christensen, M.C. (2000). The Innovator's Dilemma: When New Technologies Cause Great Firms to Fail. Harvard Business School Press.

Clausen, L. (2010). Moving beyond stereotypes in managing cultural difference: Communication in Danish-Japanese corporate relationships. Scandinavian Journal of Management, 26 (1), 57-66.

Deardorff, D. K.; Trompenaars, F.,\& Berardo, K. (2012). Building Cultural Competence: Innovative Activities and Models. Stylus Publishing.

De Genova, N. (2016). The "migrant crisis" as racial crisis: do Black Lives Matter in Europe?. Ethnic and Racial Studies, 41 (10), 1765-1782.

Di Cristini, A., Gaj, A., Labory, S. \& Leoni, R. (2003). Flat Hierarchical Structure, Bundles of New Work Practices and Firm Performance. Journal of the Italian Economic Association, 8 (2), 313-328.

Drucker, P. F. (2006). Innovation and Entrepreneurship. Harper Business.

Earley, P. C.,\& Mosakowski, E. (2004). Cultural Intelligence. Harvard Business Review, 10 (1), 57-62.

Festinger, L. (1957). A Theory of Cognitive Dissonance. Stanford University Press.

Fischer, R., Ferreira, C. M., Assmar, E. M. L., Baris, G., Berberoglu, G.,Dalyan, F., Wong, C. C., Hassan, A., Hanke, K. \& Boer, D. (2014). Organizational practices across cultures: an exploration in six cultural contexts. International Journal of Cross Cultural Management, 14 (1), 105-25.

Fitzsimmons, S. (2013). Multicultural employees: a framework for understanding how they contribute to organizations. Academy of Management Review, 38, (4), 525-49.

Friedman, J. (1994). Cultural Identity \& Global Process. SAGE Publications.

Gorski, P. (2013). Reaching and teaching students in poverty. Strategies for Erasing the Opportunity Gap. Teachers College Press. 
Habermann, F. (2008). Der homo oeconomicus und das Andere: Hegemonie, Identität und Emanzipation. Nomos: Baden-Baden.

Hall, E. T. (1959). The Silent Language. Doubleday \& Company.

Hall, E. T. (1976). Beyond Culture. Doubleday \& Company.

Hannerz, E. (1996). Performing Punk. Palgrave Macmillan.

Hassan, Z., Lashari, M., \& Basit, A. (2021). Cultivating entrepreneurial culture among students in Malaysia. Entrepreneurial Business and Economics Review, 9(1), 119-135. https://doi.org/10.15678/EBER.2021.090108

Hofstede, G. J. (1980). Culture's Consequences: International Differences in Work-Related Values. SAGE Publications.

Hofstede, G. J. (2002). Dimensions Do Not Exist: A Reply to Brendan McSweeney. Human Relations, 55 (11), $1355-$ 1361. doi: $10.1177 / 00187267025511004$

Hofstede, G. J. \& Minkov, M. (2010). Cultures and organizations: software of the mind: intercultural cooperation and its importance for survival. McGraw-Hill.

Holliday, A. (2011).Intercultural Communication and Ideology. London.

Hu, H.C. (1944). The Chinese Concept of Face. American Anthropologist, 46 (1), 45-64.

Johanson, J.,\& Vahlne, J.-E. (2009). The Uppsala internationalization process model revisited: From liability of foreignness to liability of outsidership. Journal of International Business Studies, 40 (1), 1411-1431.

Joy, S.,\& Poonamallee, L. (2013) Cross-cultural teaching in globalized management classrooms: time to move from functionalist to postcolonial approaches?. Academy of Management Learning \& Education, 12 (3), 396-413.

Kaasa, A.,Vadi, M., \& Varblane, U. (2013). European Social Survey as a source of new cultural dimensions estimates for regions. International Journal of Cross Cultural Management, 13 (2), 137-57.

Kahn, J. S. (2001). Anthropology and Modernity. Current Anthropology, 42 (5), 651-680.

Kaplan, R. B. (1966). Cultural Thought Patterns in inter-cultural education. Reprinted in K. Croft (Ed.) Readings on English as a Second Language for teachers and teacher trainers. Cambridge MA: Winthrop.

Kim, C. W., \& Mauborgne, R. A. (2015). Blue Ocean Strategy: How to Create Uncontested Market Space and Make the Competition Irrelevant. Harvard Business Review Press.

Lauring, J., Bjerregaard, T., \& Klitmøller, A. (2018). Understanding Culture in International Management: Functionalism, Constructivism, and the Emerging Practice Turn. International Studies of Management \& Organization, 48(3), 264-276. https://doi.org/10.1080/00208825.2018.1480869

Lavoie, D. (1991). Economics and Hermeneutics. Routledge.

Lewrick, M., Link, P.,\& Leifer, L. (2018).The Design Thinking Playbook. Wiley.

Mao, R. L. (1994). Beyond Politeness theory: 'Face' revisited and renewed. Journal of Pragmatics, 21(1), 451-486.

Maslow, A. H. (1943). A theory of human motivation. Psychological Review, 50(4), 370-396.

McKinsey \& Company (1993). Born global. The McKinsey Quarterly, 4 (1), 45-63.

McKinsey \& Company (2020). Problems amid progress: Improving lives and livelihoods for ethnic minorities in the United Kingdom. McKinsey Global Publishing.

Myers, I. B. (1962). The Myers-Briggs Type Indicator: Manual (1962). Consulting Psychologists Press.

Nathan, G. (2014). Multi-stakeholder deliberation for (Global) justice: An approach from modern civic republicanism. In S. Schepers, A. Kakabadse (Eds.) Rethinking the Future of Europe: A Challenge of Governance (pp. 10-27).Palgrave Macmillan.

Olwig, F. K. (1997). Introduction and Cultural Sites: Sustaining a Home in a Deterritorialized World. In F.K. Olwig \& K. Hastrup (Eds.), Siting Culture: The Shifting Anthropological Object ( pp.23-47). Routledge.

Pan, Y. (2000). Politeness in Chinese Face-to-Face Interaction. Ablex Publishing.

Pearce, C. L. (2003). The future of leadership: Combining vertical and shared leadership to transform knowledge work. Academy of Management Perspectives, 18 (1), 47-57.

Pearce, C. L.,\& Conger, J. A. (2002). Shared Leadership: Reframing the Hows and Whys of Leadership. SAGE Publications.

Primecz, H., Romani, L., \& Sackmann, S. (2009). Cross-Cultural Management Research: Contributions from Various Paradigms. International Journal of Cross Cultural Management, 9(3), 267-274. 
Radziszewska, A. (2014). Intercultural dimensions of entrepreneurship. Journal of Intercultural Management, 6(2), 35-47. https://doi.org/10.2478/joim-2014-0010

Ries, E. (2012). Lean Startup: Schnell, risikolos und erfolgreich Unternehmen gründen. Redline.

Rumelt, R. (2011). Good Strategy Bad Strategy: The difference and why it matters (4th ed.). Profile Books.

Sayer, A. (1997). Essentialism, Social Constructionism, and beyond. SAGE Journals, 45(3), 453-487.

Scollon, R.,\&Scollon, S. (2001). Discourse and intercultural communication. In D. Schiffrin, D. Tannen, \& H. E. Hamilton (Eds.), The handbook of discourse analysis (pp.538-547). Blackwell Publishers.

Schumpeter, J. A. (1942). Capitalism, Socialism, and Democracy. Harper.

Sinek, S. (2009). Start With Why. Penguin LCC US.

Singh, J. V., Tucker, D. J.,\& House, R. J. (1986). Organizational Legitimacy and the Liability of Newness. Administrative Science Quarterly, 31 (2), 171-193.

Søderberg, A. M.,\& Holden, N. (2002). Rethinking cross cultural management in a globalizing business world. International Journal of Cross Cultural Management, 2 (1), 103 - 121.

Spencer-Oatey, H. (2002). 'Managing rapport in talk: using rapport sensitive incidents to explore the motivational concerns underlying the management of relations. Journal of Pragmatics, 34 (5), 529-545.

Start Up Wissen (2020). Warum scheitern StartUps? Die 20 häufigsten Gründe. Retrieved 18.02.2021 from https://startupwissen.biz/daran-scheitern-die-meisten-startups/

Swart, K.,\& Maralack, D. (2020). Black Lives Matter: perspectives from South African cricket. Sport in Society: Culture, Commerce, Media, Politics, 23 (11), 1-16.

Szromnik, A. (2019). Market and marketing within the concept of functioning and development of cultural heritage sites. International Entrepreneurship Review, 5(3), 79-94. https://doi.org/10.15678/IER.2019.0503.06

t3n (2016). Warum Startups scheitern: Das sind die 20 häufigsten Gründe. Retrieved from https://t3n.de/news/startups-scheitern-20-569194/ on 27.01.2021.

Taylor, K.-Y. (2016). From \#BlackLivesMatter to Black Liberation. Haymarket Books.

Trompenaars, A.,\& Hampden-Turner, C. (1997). Mastering the infinite game: how East Asian values are transforming business practices. Capstone.

Usunier, J.-C. (2011). Language as a resource to assess cross-cultural equivalence in quantitative management research. Journal of World Business, 46(3) 314-319.

Voloshinov, V. N., Matejka, L.,\&Titunik, I. R. (1973) (original 1929). Marxism and the philosophy of language. Seminar Press.

Wach, K. (2015). Impact of Cultural and Social Norms on Entrepreneurship in the EU: Cross-Country Evidence based on GEM Survey Results. Zarzqdzanie $w$ Kulturze, 16(1), 15-29. https://doi.org/10.4467/20843976ZK.15.002.3037

Wąsowicz-Zaborek, E. (2018). Influence of national culture on website characteristics in international business. International Entrepreneurship Review, 4(3), 421-442. Retrieved from https://ier.uek.krakow.pl/index.php/pm/article/view/1783 on 27.01.2021.

Wendt, D. C., \& Gone, P. J. (2011). Rethinking cultural competence: Insights from indigenous community treatment settings. SAGE Journals, 49 (2), 206-222.

Weinberg, U. (2019). Design Thinking: Vom Innovationsmotor zum Kulturtransformator. In Von Engelhardt, S. \&Petzolt, S. (Eds.), Das Geschäftsmodell Toolbook für Digitale Ökosysteme (pp. 36-49).Campus. 


\section{Authors}

The contribution share of authors is equal and amounted to $50 \%$ for each of them.

KB - conceptualisation, literature writing, PS - methodology, calculations, discussion.

\section{Kerstin Bätz}

Graduate Student at the International School of Management in Frankfurt (Germany).

Correspondence to: Ms. Kerstin Bätz, International School of Management, Germany, e-mail: kerstin.baetz.2019@student.ism.de

ORCID (i) http://orcid.org/0000-0002-6345-5104

\section{Patrick Siegfried}

Professor of Supply Chain Management and Logistics at the International School of Management (ISM) in Frankfurt (Germany). Guest Professorship for Entrepreneurship at the Szent István University in Gödöllö (Hungary). He has professional experience as a CEO of various logistics companies and as a commercial manager for an international distribution centre. His research focuses is on Strategic Management and Innovation Management in Startups.

Correspondence to: Prof. dr Patrick Siegfried, International School of Management, MörfelderLandstraße 55, 60598 Frankfurt am Main, Germany, e-mail: patrick.siegfried@ism.de ORCID (1) http://orcid.org/0000-0001-6783-4518

\section{Acknowledgements and Financial Disclosure}

The authors would like to express their gratitude to Dr. Vivien Zhou and Dr. Nick Pilcher for their valuable knowledge delivery on linguistics and culture in the managerial context, Pascal Schaarschmidt for critically reflecting on the draft version of this paper, and Nathalie Schwarzkopf for her inspiration.

\section{Conflict of Interest}

The authors declare that the research was conducted in the absence of any commercial or financial relationships that could be construed as a potential conflict of interest.

\section{Copyright and License}

This article is published under the terms of the Creative Commons

Attribution - NoDerivs (CC BY-ND 4.0) License

http://creativecommons.org/licenses/by-nd/4.0/ 